\title{
The 'firstness' of male as automatic ordering: Gendered discourse in Southern African Business Studies school textbooks
}

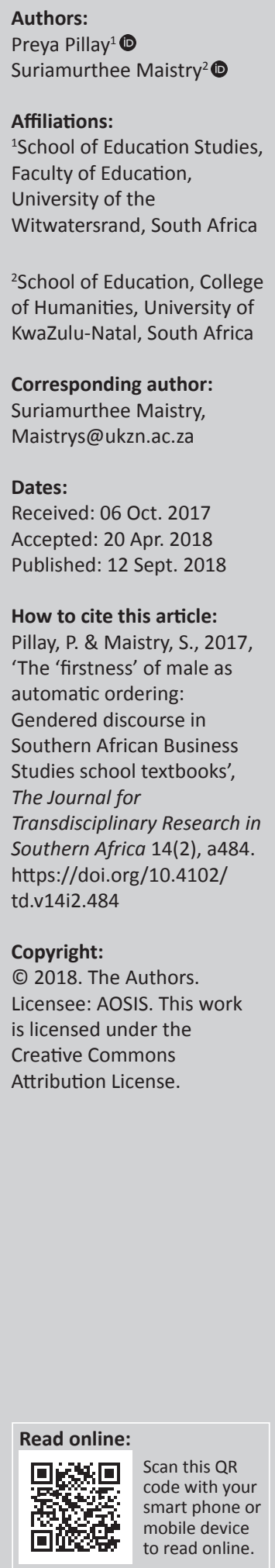

Authors:

Affiliations:

Faculty of Education,

University of the

${ }^{2} S$ chool of Education, College of Humanities, University of KwaZulu-Natal, South Africa

Corresponding author: Suriamurthee Maistry,

How to cite this article:

'The 'firstness' of male as

automatic ordering:

dered discourse

Studies school textbooks',

The Journal for

https://doi.org/10.4102/

$14 \mathrm{i} 2.48$

Copyright:

Licensee: AOSIS. This work

is licensed under the

Creative Commons

Attribution License.

to read online.
There is little contention that gender equity continues to be a challenge in many societies across the Southern African region. Dominant discourses that perpetuate inequality are often reflected in school materials such as textbooks, which have the potential to socialise girls and boys into particular gender performances. The aim of the study being reported on was to examine representations of gender in a sample of Business Studies school textbooks. The textbooks were selected from four Southern African countries: Swaziland, Lesotho, Zimbabwe and South Africa. The study employed a sociolinguistic analytical framework, namely critical discourse analysis and was guided by the tenets of feminist poststructuralism in the analysis of this phenomenon. The findings of the study reveal superficial content changes in the texts under study. Gendered ideologies continue to prevail in a remarkably overt fashion. One key finding was at a semantic level, namely the mention of the male pronoun first in sentences and conversation and not the female pronoun, having the likely effect of endorsing the principle of the 'firstness' and superiority of the masculine. In the order of two words paired for sex such as 'Mr and Mrs', 'brother and sister' and 'husband and wife', the masculine word came first. This automatic ordering is likely to reinforce the second-place status of women. The article concludes with a discussion on the implications of these findings for pedagogy and the textbook publishing industry. The findings also have the potential to ignite debate, as it relates to re-imagining the programmatic curriculum (school textbooks) as a contested genre.

\section{Introduction and background}

Since the early 1960s, gender equity has received unprecedented attention at international forums (Weedon 1997). There is a growing international understanding that gender equity is a prerequisite to achieving human and sustainable development. To this end, a number of declarations have been promulgated, for example the Convention on the Elimination of All Forms of Discrimination against Women (CEDAW), UNICEF Policy on Gender Equality, Empowerment of Girls and Women, Commonwealth Plan of Action for Gender Equality 20052016, the Millennium Development Goals and the Education of Girls to Promote Gender Equity. In 2010, Southern African Development Community (SADC) leaders also committed themselves to enhancing quality education and removing gender stereotyping in the curriculum and career choices. Although there has been gradual progress, many alarming issues, regarding gender discrimination, still prevail. Gender equality has to be elevated to a global priority as a fundamental step in both human development and economic progress (UN Summit 2010:6). Gender discrimination is rooted in history, tradition and culture (Rosenberg 2001). Research in sub-Saharan Africa has found that despite legislation and policies to improve gender equality, socialisation into gender roles and values reinforce gender inequality (Bhana 2009; Mahlomaholo 2010; Morojele 2010). The dominant discourses of gender continue to give dominance to types of masculinities and femininities in ways that 'uphold inequitable gender relations and reinforce patriarchy' (Morojele 2012:82).

One way in which dominant discourses promote selective values is through school textbooks (Apple \& Christian-Smith 1991; Crawford 2003; Davids 2013; Fan \& Zhu 2007; Naidoo 2014; Osborne 2004; Pillay 2013; Pingle 2010). Textbooks, by nature, tend to control knowledge as well as transmit it and to reinforce selected cultural values. Textbooks are therefore not only powerful, but also embedded in ideological discourses. It is this ideological discourse that becomes the official, state-sanctioned narrative from which learners are to learn certain values and beliefs (Engelbrecht 2007). Therefore, textbooks do not stand as neutral entities 
espousing agreed or accepted 'historical truths' (Foster 2011), but rather as powerful cultural artefacts, containing the ideas, values and knowledge that influential elements in society expect students to know and embrace. They are '... conceived, designed and authored by real people with real interests' (Apple 2001:46). Selection of textbook knowledge is therefore an intensely political activity, often leading to tension, controversy and acrimonious debates in the struggle to define what (or whose) knowledge is of most worth.

With regard to school textbook selection, the state in many African countries is largely responsible for approving 'suitable' textbooks (Eric 2011). The textbooks that are endorsed by the state need to present knowledge selections in accordance with the content listed in the prescribed curriculum of the country. Ministries of education in African countries generally scrutinise the textbooks through a screening and quality assurance process at various stages of the textbook production process (Eric 2011) to ensure that textbooks cover the prescribed curriculum. Ministries of education also have the power to veto sections in a textbook that do not fit the educational ideology promoted by the official curriculum.

For these powerful reasons there can be no certainty that gender equity will be an agenda that might be prioritised in the programmatic curriculum (in textbooks). The symbolic representations in the textbooks are connected to real power relations, and they might also represent differentiated social relations as natural and unquestionable (Sleeter \& Grant 1991). Of significance, though, is that there is limited understanding of the nature of content selections that textbook authors invoke and the subtext thereof (Cameron et al. 2003). Thus, it is imperative to review textbooks to uncover the hidden, underlying assumptions and stereotypes within their content (Foster \& Crawford 2006).

The focus of this article is therefore to understand the way in which gender is represented in four Business Studies textbooks selected from countries in the SADC region and to theorise about their particular representation. More specifically, the focus of this study is to understand how gender is represented in the four SADC textbooks so as to develop a theoretical explanation for how the phenomenon presents. The four SADC countries have introduced various policies on gender equity of which an example is the 50/50 policy underpinned by the CEDAW which provides guidelines and procedures for gender equity (Mukundan \& Nimehchisalem 2008). However, it is important to examine the extent to which the principles outlined in such policies are given effect in Business Studies school textbooks.

While textbook research is a growing field, Business Studies textbook analyses are limited (Collison 2003) even though international scholars have argued that Commerce Education texts have great potential to promote ideologies in keeping with patriarchy and discrimination (McPhail 1996; Zhang 2012).
In spite of these concerns, few studies have been conducted on the analysis of Business Studies textbooks across the selected SADC countries, and none in the last phase of high school. As such, one might infer that the knowledge and skills about critical textbook use may not have been foregrounded in teacher education programmes. The skills of a critical linguist (using critical discourse analysis [CDA]) are essential if individuals (teachers and learners) wish to unearth the subtext of school textbooks. The aim of this article is therefore to illuminate ideological representations at work in the selected texts.

\section{Literature review}

To read language as having assumed common meanings can lead to very different interpretations. Words have not only explicit connotations, but also implicit connotations. For example, does the word 'man' refer only to a biological being, or does it also imply moral characteristics, positions of power and legitimacy that go far beyond this? Words do not contain a single, present meaning; they defer their meaning to other words in the language system. As a result, meaning is always slipping and sliding, and language is therefore not an accurate tool to represent reality (Foucault 1991). Meanings will always be partial, contingent and contextual and open up an endless play of interpretation. Sexist language entails exclusion, degradation and stereotyping of women.

Foucault (1991:3) argued that 'our discourse shapes our reality', that issues of power are invested in our discourse and languages. For Foucault, symbols reflect power. As such, male pronouns, as a generic, reflect society's views of power. These regimes of power are reflected in our ways of speaking and writing about the world, and gender is one component of the way in which power and privilege interact with language.

As early as the 16th century, it was proclaimed that males should be mentioned before females: 'let us keep a natural order and set the man before the woman for manners' sake', for 'the Masculine gender is more worthy than the feminine' (Eckert \& McConnell-Ginet 2003:34). This ordering, reflecting a widespread perception of male supremacy, has been conventionalised and not questioned until relatively recently. The notion of the natural order has been criticised by various theorists (Butler 1990; Foucault 1991; Sugino 1998) who refute the notion of 'natural', claiming that discourse is a reflection of cultural, ideological and political values of certain groups in society. 'Discourses represent political interests, and in consequence are constantly vying for status of power' (Weedon 1987:41). Through webs of power, certain knowledge comes to be valorised and accepted as the norm.

An early study of Australian and Commonwealth countries' language textbooks revealed use of male pronouns as generic (Davis 1995). This would mean that most references to the professions were to male persons (Davis 1995). The same was 
found with the use of 'he' as a generic term throughout the texts of Commonwealth countries in Asia. The author remarks that use of the generic 'he' would lead the readers to believe that all of the characters were males. Apple and ChristianSmith (1991) suggest that the inclusion and exclusion of knowledge in textbooks constructs a distinct economic and historical reality. Textbooks spread ideologies while conveying facts under the guise of 'historical legitimacy' (Davis 1995:12), a finding confirmed by Foroutan (2012).

The issue of 'firstness' of pronouns began in Modern English when the meaning of 'man' was broadened:

In seventh-century [sic] the word 'man' originally included and was applied to both sexes. In Old English 'man' as a term meant 'person' or 'human being' and could not be used to identify a male person. (Festante 2013:10)

The ambiguous use of 'man', referring not only to humankind, but also to a male person in particular, caused trivialisation and degradation of women. Festante (2013) maintains that, using a generic form of the word 'man', diminishes women to lesser importance than men. Even though there are alternatives to avoid the use of gender-marked items, many textbook authors continue to apply the word 'man' in its generic use.

Likewise, a study on gender stereotypes in children's literature in Japan and America revealed the use of generic terms like 'he', 'man' and 'mankind' to represent human beings (Swainson 2016). A masculine term was used as a generic term as proper form, thus tightly linking sexism with language (Swainson 2016). Whenever a generic term is needed, the masculine term is used as a proper form, compared to lesser use of 'her' or 'she'. This often determines the elite and legitimate culture that textbook authors wish to pass on (Apple 1991). The findings on Iranian and Turkish textbooks (Skliar 2009) as well as Swedish textbooks (Mustedanagic 2010), for example, reveal that the construct of the female businessperson is largely missing. It is therefore assumed as 'fact' - that should be taught to children - that the world of business is a masculine space.

A more recent analysis of English first language textbooks used in Iran revealed that 14 personal pronouns were used to refer to females, whereas 51 pronouns referred to males (Baghdadi 2012:69). Frequency of usage of pronouns showed that men were more frequently portrayed and described in the textbook, although there were several examples of the generic 'person' being used to refer to both males and females. States Baghdadi (2012:69): 'This education should prepare the person for the job he can do best' and 'when someone fasts, it means he doesn't eat'. Generic usage of 'he' clearly delineates females as inferior to males. The sense created here is that the masculine pronoun can be used as a general word. Specific use of the feminine pronoun, however, distinctly denotes that which is not masculine. In so doing, it gives effect to an unwitting othering as patterns favour masculinity as generic.
Firstness of pronouns is another feature of language where gender discrimination can easily be observed (Eckert \& McConnell-Ginet 2003). This represents a common conviction that men are more important than women in almost every society, suggesting that it is necessary to place them first everywhere. 'Firstness' refers to the linguistic feature where one particular gender is often mentioned first (Pillay \& Maistry 2013).

Analysis of gender firstness in textbooks was first undertaken in 1978 in an investigation of several textbooks published over a period of 12 years (Hartman \& Judd 1978). The authors proposed that many texts presented needlessly stereotyped portrayals of men and women, whether through one-sided role allocation, overt put-downs or omission (Hartman \& Judd 1978). The order of mentioning two nouns, such as 'Mr and Mrs', 'brother and sister' and 'husband and wife', was investigated - and the masculine word always came first. This automatic ordering reinforces the second-place status of women.

Five years later a study sought to determine whether change had occurred since the Hartman and Judd analysis (Porreca 1984). In a quantitative investigation, focusing on female visibility and firstness in sentences where 15 textbooks were evaluated, the findings confirmed those of Hartman and Judd, and indicated that sexism in English First Language (EFL) textbooks was still a problem. Women were mentioned half as often as men were, firstness for men was three times as prevalent as female firstness and women were less visible in occupational roles (Porreca 1984). The author also noted that when two gender-specific nouns or pronouns appeared as a pair, like 'mother and father' or 'he or she', the one appearing first could be interpreted as having higher status. This, she maintained, reinforces the stereotypical notion of who is regarded as more worthy and important in society. Textbooks therefore have a way of telling less than the truth by reflecting the ideology of the dominant worldview.

Similar firstness tendencies were found in a sample of Hong Kong textbooks (Lee \& Collins 2010). This ordering of the male first reinforces the second-place status of women (Lee \& Collins 2010), and these authors suggest mixing the order, because female learners will feel weak and unimportant in comparison to male learners. The ideology of masculine superiority will also affect female learners' self-esteem.

Bias in EFL textbooks was evident: when masculine and feminine nouns occurred together, the male noun usually came first (Healy 2010). This type of language usage was regarded as conventional usage (Bahman \& Rahimi 2010), an issue that might be addressed by critically engaging learners in understanding that such usage is not restricted by grammatical rules or convention and that they could choose which gender to use first (Healy 2010). Finally, the analysis of Iranian high school EFL textbooks revealed that men were mentioned before women in the majority of cases (Amini \& Birjandi 2012:137). In one of the books, there were 12 first 
mentions of males and only two first mentions of females. The researchers explained this linguistic feature as representing the traditional patriarchal view of women in Iranian society; deeply rooted traditions show that men always come first and that women are subordinate to men. A key omission from the findings is the authors' failure to comment on how Iran, being a 'patriarchal' society, ranks equally with all the other countries in terms of gender inclusivity. This omission serves to conceal issues of power and ideology. To this effect, textbooks are described as 'both pedagogical and political' (Aronowitz \& Giroux 1991:215).

The foregoing literature confirms the socially constructed nature of textbooks. It also signals the need for a critical approach to textbook use. Of concern is the dearth of researchbased knowledge on the content of Business Studies textbooks and the ideology that might present, in this important teaching resource, an issue that we attempt to foreground through this article.

\section{Theoretical framework}

A feminist poststructuralist perspective was employed as a theoretical lens to examine gender representation in the selected school textbooks. The specific analytical framework was drawn from feminist CDA. The specific locus of interest in feminist poststructuralism is language as a site for the construction and contestation of social meanings. Feminist poststructuralists believe that language (which includes visuals) provides the means for people to think, speak and give meaning to the world around them (Weedon 1987:12). Through language, people internalise social norms and social perceptions of reality, thereby becoming members of society. It is through language that gender is socially constructed, as gender differences dwell in semantics. Through language, the individual makes sense of social and cultural experiences and provides informative explanations of those experiences (Baxter 2002; Wetherell 1999).

When viewed as more than vocabulary and grammatical rules, language becomes the way we construct meaning and understanding of our world (Scott 1988). Feminist poststructuralism challenges gender categories as dual, oppositional and fixed, arguing that gender comprises shifting, fluid multiple categories. Hence, stable definitions of gender are challenged (Aikman \& Unterhalter 2005). Feminist poststructuralism seeks to explain the emergence, becoming or genesis of structures, or how systems such as language come into being, mutate through time and give meaning to the world of a particular gender. Such systems are therefore neither fixed nor stable (Deleuze 1988). As a common factor in any analysis of power, social meanings and construction of identities, language must be a central site of analysis. This is where actual and possible forms of social organisation and their social and political consequences are defined and contested. Crucially, language is where subjectivity - which feminist poststructuralism sees as a site of disunity and conflict - is constructed (Weedon 1997).
Feminist poststructuralist theoretical perspectives on language and discourse therefore present as a useful analytical tool with which to deconstruct the language of Business Studies textbooks and expose gender and other constructs embedded in the discourse. The act of deconstructing texts will help reveal the constant performance of the different elements within language, as it entails interpreting a text by exposing what is usually suppressed.

\section{Methodology}

The study adopted a critical paradigmatic orientation as a means of exposing, underlying assumptions and gendered ideologies that serve to construct power relations via the 'representations' in the textbooks. The methodology employed was CDA. A major concern for critical analysts is how texts can be representations of ideologies, and can contribute to social relations of power and domination. Critical discourse analysis can reveal how certain ideologies are dispersed through discourses of the education system at the micro level of Business Studies textbooks and the macro level of a social agenda or political intervention.

For this study, Fairclough's (2001) three-dimensional CDA framework was used. The devices in Fairclough's (2001) threedimensional framework used for analysis of text and discourse in this study were as follows: (1) linguistic description of the formal properties of the text; (2) interpretation of the relationship between the discursive processes and interaction, and the text, where text is the end product of a process of text production and a resource in the process of text interpretation; and (3) explanation of the relationship between discourse, and social and cultural reality.

The linguistic description phase of Fairclough's threedimensional analysis of texts was done, using a specific framework adapted from Machin and Mayr (2012), and selected because of the benefits it offers in categorising choices made within discourse via socio-semantic rather than lexicogrammatical meaning, as it offers an opportunity to analyse the textbooks in terms of the social context it might be used in.

Key analytical constructs (see Table 1), used at the description phase of this study, included foregrounding, backgrounding, embellishments, assumptions, silences and omissions, nominalisation, modality, presupposition, pronoun versus noun, nomination and functionalisation, impersonalisation, personification and objectification, honorifics, aggregation, synecdoche, and register.

In addition to using Fairclough (2001) as well as Machin and Mayr's (2012) representational framework, the following basic steps for using CDA, as outlined by Huckin (1997), guided our initial analysis. Firstly, we read the chapters selected in the textbook in an uncritical manner. Then we reread the chapters in a critical manner by raising questions about them and establishing how they could be constructed differently. In the next step, we looked for the perspective being presented which is referred to as framing the details into a coherent whole. 
TABLE 1: Selected categories from the Social Actor Network and their representative meaning.

\begin{tabular}{|c|c|}
\hline CDA protocol & Explanation of CDA protocol \\
\hline Aggregation & When participants are quantified and treated like statistics. \\
\hline \multirow[t]{4}{*}{ Modality } & $\begin{array}{l}\text { The tone of the text conveyed by the use of modal verbs, adverbs } \\
\text { and adjectives. Modality can also be associated with hedging } \\
\text { terms, such as 'I think', 'kind of', 'sort of', 'seems' or 'often'. }\end{array}$ \\
\hline & $\begin{array}{l}\text { Epistemic modality: To do with the author's judgement of the } \\
\text { truth of any proposition. In other words, epistemic modals show } \\
\text { how certain the authors are that something will happen or is the } \\
\text { case (e.g. 'I think this might be the correct procedure'). }\end{array}$ \\
\hline & $\begin{array}{l}\text { Deontic modality: To do with influencing people and events. } \\
\text { Deontic mode is about how we compel and instruct others } \\
\text { (e.g. 'Students must do the activity'). }\end{array}$ \\
\hline & $\begin{array}{l}\text { Dynamic modality: This is related to possibility and ability but } \\
\text { is not subjective in the manner of the first two modalities } \\
\text { (e.g. 'You can do your homework'). Here the author is not so } \\
\text { much expressing her or his judgement or attempting to influence } \\
\text { others but is indicating ability to complete an action or the } \\
\text { likelihood of events. }\end{array}$ \\
\hline $\begin{array}{l}\text { 'Taken-for-granted' } \\
\text { words and } \\
\text { assumptions }\end{array}$ & $\begin{array}{l}\text { ' Using certain words that take certain ideas for granted. A reader } \\
\text { is therefore unlikely to question what is known to be common } \\
\text { knowledge. This is presented as having no alternative and } \\
\text { obscuring what could have been stated, assigning a meaning } \\
\text { without exploring any other meanings, because people are } \\
\text { products of their cultures, experiences and society. } \\
\text { 'Assumptions' are statements that imply that the meaning of } \\
\text { what is written is taken as true or is sure to happen, although } \\
\text { there is no factual proof of this. }\end{array}$ \\
\hline Register & Single words can suggest that words that are spoken ring true. \\
\hline $\begin{array}{l}\text { Omissions or } \\
\text { lexical absences } \\
\text { or suppression }\end{array}$ & $\begin{array}{l}\text { Leaving out certain things; a silence on pertinent issues. } \\
\text { 'Omissions' are identified through the exclusion and suppression } \\
\text { of information that can be motivated politically or socially. }\end{array}$ \\
\hline Nominalisation & $\begin{array}{l}\text { Changing a verb into a noun often used to generalise an issue. } \\
\text { Nominalisations are also used to connote and imply a meaning } \\
\text { through metaphors and figures of speech. Investigating } \\
\text { metaphorical metaphors can be an effective tool in researching } \\
\text { and identifying a particular ideology of a social system, as we use } \\
\text { metaphors in our daily lives to explain events or things to others } \\
\text { and ourselves. }\end{array}$ \\
\hline Embellishments & $\begin{array}{l}\text { Using diagrams and sketches to get the reader's attention. These } \\
\text { can also be used to imply that the content is scientific, thereby } \\
\text { adding weight to arguments. }\end{array}$ \\
\hline $\begin{array}{l}\text { Foregrounding, } \\
\text { backgrounding }\end{array}$ & $\begin{array}{l}\text { Using keywords to emphasise certain concepts. } \\
\text { A writer can use titles and keywords to stress the importance of } \\
\text { certain ideas by placing them in a prominent place textually to } \\
\text { influence the reader. This is called 'foregrounding', but if there is } \\
\text { minimal mention of a concept, it is called 'backgrounding'. }\end{array}$ \\
\hline Presupposition & $\begin{array}{l}\text { Using words that take certain things for granted, as if there is no } \\
\text { alternative. }\end{array}$ \\
\hline Over-lexicalisation & $\begin{array}{l}\text { The availability of many words for one concept; it indicates the } \\
\text { prominence of the concept in a community's beliefs and } \\
\text { intellectual interests. }\end{array}$ \\
\hline
\end{tabular}

Source: Adapted from Machin and Mayr 2012

CDA, critical discourse analysis.

Finally, we closely analysed sentences, phrases and words, looking for (among other things) language that conveyed power relations, insinuations and tone - three linguistic elements between which CDA particularly seeks to identify connections.

In analysing and interpreting the visual data, we adapted the framework designed by Nene (2014) (see Box 1). Her framework takes into consideration various aspects of visual representation which is useful for this study. Her framework has a specific gender focus.

The textbook sample for this study constitutes Business Studies textbooks from four SADC countries (South Africa, Swaziland, Zimbabwe and Lesotho) and drawn from the last phase of high school (preceding tertiary education). The textbooks were chosen on the basis of their popularity and endorsement by the Ministry of Education. We have chosen to analyse only the sections on the topic 'entrepreneurship' in order to ascertain the extent to which this historically masculine domain has engaged the gender equity agenda.
BOX 1: Framework for analysing visuals.

What kind of source or visual is it?
Origin: where was the image taken?
Gender? Girls and boys were analysed on their activities, sports, preferences in
different things to do and the different roles that were available to them. Physical
features and appearance such as clothes and accessories were used to determine
the different sexes.
Race (African, white, Indian or coloured, other)? Races were analysed on physical
signifiers such as skin colour and hair texture as well as on what they were seen
to be doing in terms of work, social activities such as sport or cultural activities,
where they lived and what they did where they lived.
Why are they depicted in this manner (historically)?
What information about the image is shared?
What information is excluded?
What is the connotation of the image?
What is the denotation of the image?

Source: Nene 2014

Entrepreneurship, as a topic, comprises a key topic in the Business Studies textbook content. As such, it offered a substantive data corpus for analysis. Note that, although textbooks are in the public domain, pseudonyms were used to keep identities anonymous.

\section{Findings}

In the foregoing analysis, we demonstrated how language affirms the masculine across all four Business Studies textbooks under study where sexist and biased language was used to reinforce male dominance. Evidence of this can be seen in the recurring representation of firstness of male pronouns and use of the generic 'man' across the texts.

\section{Firstness of the male noun reinforces gender bias}

'Firstness' refers to the mention in texts of men first before women. It is about prioritising men ahead of women. More often than not, in the order of two words paired for sex, such as 'Mr and Mrs', 'brother and sister' and 'husband and wife', the masculine word comes first. This automatic ordering reinforces the second-place status of women and is one of the ways in which the power status of men is reinforced. All the instances in which the two genders were mentioned together in the four textbooks were analysed to inspect which appeared first. The findings revealed the following: males were in the first position most times, while females were in first position in only three instances (see Table 2).

This pattern reinforces the stereotypical notion that womanhood has a second-place status and therefore that females are not as important as males. Across all four textbooks from the four selected countries, the authors reinforce the notion of masculine firstness. Of particular significance is that this pervasive ordering develops and sustains a 'naturalness' and a taken-for-granted 'normalness' of this gendered order.

\section{Examples of recurring pattern of firstness of male pronouns}

The following examples highlight some of the recurring patterns of firstness of male pronouns across the four textbooks:

Men and women have equal opportunities in the workplace. They are treated with respect and dignity. (Lesotho, p. 22) 
TABLE 2: Firstness of male and female nouns and pronouns.

\begin{tabular}{|c|c|c|c|c|}
\hline \multirow[t]{2}{*}{ Nouns and pronouns } & \multicolumn{4}{|c|}{ Frequency } \\
\hline & Lesotho & Zimbabwe & South Africa & Swaziland \\
\hline \multicolumn{5}{|l|}{ Firstness of male nouns } \\
\hline He or she & 10 & 14 & 11 & 10 \\
\hline His or hers & 12 & 12 & 10 & 11 \\
\hline Male name before female (e.g. 'Patrick and Lisa') & 12 & 22 & 18 & 13 \\
\hline Boys and girls & 4 & 3 & 1 & 1 \\
\hline Businessmen or businesswomen & 0 & 0 & 0 & 0 \\
\hline Men and women & 8 & 19 & 13 & 10 \\
\hline Mr and Mrs & 4 & 3 & 2 & 4 \\
\hline \multicolumn{5}{|l|}{ Firstness of female nouns } \\
\hline Female name before male ${ }^{a}$ & 1 & 0 & 1 & 1 \\
\hline Total & 1 & 0 & 1 & 1 \\
\hline
\end{tabular}

a,No other category reflected the female noun before the male.

While the authors appear to have sought to advocate gender equality, it seems that they may have inadvertently intensified the differentiation. The text is written, using the male first person pronoun before the female noun, unwittingly according priority to the masculine. An essentialist gender polarity is created, suggesting that a person could only either be a man or woman. This normalising judgement with its distinct categorical classification does not allow for any ambiguity or ambivalence in gender identity. This sentence is written in the declarative mode which appears to assert the content as a universal truth. Heterosexual sex is thus established as the norm. The declarative mode, as Fairclough (2001) points out, can be an indicator of asymmetrical relations of power; in this instance, the authors are placed in the position of being the possessors and providers of knowledge while the readers are receivers. Because textbooks are seen by students as holding unquestionable truths, they will accept this version of reality as the truth:

If an entrepreneur wants to be successful, he or she must choose how best to use scarce resources to satisfy as many needs and wants as possible. (Swaziland, p. 110)

Again, the male pronoun comes before the female pronoun, signalling relative importance. Binary polarity is also reinforced which defines gender simplistically: 'he or she', in which the reader is either of the masculine or feminine gender:

Jalil and Mayra both have equal amounts of money to invest or save. Jalil chooses to save his money in a bank that pays an annual rate of interest. Mayra chooses to invest her money in a small beauty salon, which is far more risky. (Zimbabwe, p. 306)

The identities and aspirations of Jalil and Mayra are depicted as polar opposites: male/female. The authors construct the idea that this woman has not given the venture of entrepreneurship sufficient thought and might be ignorant of potential risks. Although the authors portray women as individuals who would like to start a business, the business is referred to as 'small'. This example suggests that women are not likely to be sufficiently skilled to own and maintain large businesses. Another phenomenon that comes to the fore is the gender-stereotyped occupations. The business to which Mayra aspires is not just a small business, but also one that is typically female-orientated. Learners would assume that such activities are the domain of women and not men.

In the next instance, the text once again foregrounds the masculine pronoun before the female pronoun:

$\mathrm{Mr}$ and Mrs Gordon, owners of an upholstery factory, are certain that the strike has prevented workers from entering the plant. Mr Gordon announced that the company won't stand for it and requires staff to resume work or face disciplinary action ... The striking workers hung around the company singing to show dissatisfaction. (South Africa, p. 195)

From the quoting verb 'announced', we are able to draw out more precisely what is connoted. Those who 'announce' things, appear to have power and legitimacy, and have the ability to take control. In this case, it is Mr Gordon as opposed to Mrs Gordon. There is a tendency for textbook writers to adhere firmly to the convention of mentioning males before females when husband and wife ( $\mathrm{Mr}$ and Mrs Gordon) are used together as generic pronouns. This order of appearance suggests male supremacy and the second-place status of women (Hartman \& Judd 1978; Lee \& Collins 2010).

\section{The generic 'man'}

Even though there are alternatives to avoid gender-marked item usage, the authors across the four textbooks, still apply the word 'man' generically, diminishing women as being less important than men. Examples of this are discussed in the texts below:

By now, you should know that to be a successful businessman you must make a profit. (Zimbabwe, p. 58)

This statement reflects bias. The authors could have used a more neutral pronoun such as 'businessperson' instead of 'businessman' as a way not to favour a particular gender. In the absence of the female noun 'businesswoman', the authors reinforce the message that entrepreneurship and owning businesses is an exclusive entity best suited for males. As Lee and Collins (2010) argue, this type of presentation might reinforce stereotyped views of male and female roles and abilities among students. The adjectival clause ' $[b]$ y now, you should know' implies that the balance of the sentence that 
follows, conveys information that is common knowledge and requires no further investigation or examination, because its import is perceived to be 'natural' and selfevident. The use of the pronoun 'you' communicates that the authors make certain assumptions about the outlook and nature of the reader. Again, it also appears to convey the impression that the meaning, contained in the sentence, is a shared view held by all 'right-thinking' people. The deontic modal verb 'should' adds to this impression, denoting moral obligation of the reader to accept the statement as a fact. This perspective on profit is presented as if there are no other factors that play a significant role in becoming a successful businessman:

Managers should help employees feel valued. They should guide and equip workers to achieve the organisation's goals. A democratic manager consults with his workers. (Lesotho, p. 354)

While the first two sentences appear to be tentative and using gender neutral language, and may be interpreted as nonspecific, in the third the word 'his' is used which makes the gender more explicit and entrenches the view of a taken-forgranted assumption that men are managers. The writers could have chosen the phrase 'with workers', but the use of the pronoun 'his' betrays the author's bias and proclivity for the masculine. Omission of the female noun 'manageress' adds to this bias. Along with this biased assumption of men as managers, the picture that follows this definition, foregrounds the masculine gender as managers. The modal auxiliary 'should' has both a relational and an expressive modality. It implies either allowing for the possibility or having the authority to make employees feel valued. The responsibilities attributed to managers denote them as important figures in an organisation. The infinitive verbs 'guide' and 'equip' suggest that the subject is pastoral in nature, while the infinitive 'to equip' would clearly state that the subject is aligned with what is perceived to be greater economic imperatives.

The picture in Figure 1 influences the biased assumption (albeit an unrealistic one) of a sexist ideology that management is a masculine occupation, and the writers do very little to trouble this perception.

Jake declared that many workers are unhappy ... He suggested to the Chairman to address this in his agenda. (Swaziland, p. 218)

The metapropositional verb 'declared' marks the author's interpretation of the speaker: the word appears to be a true report and makes Jake appear more assertive. The text also heightens the bias and stereotypical representation of men as chairpersons in an organisation. The authors could have been more neutral by referring to the 'chairperson' as opposed to 'chairman'. The sentence could have read ' $[h]$ e suggested to the chairperson to address this in the agenda' to be more gender neutral; using the masculine pronoun 'his' and 'chairman' betrays the author's bias. No female is presented in this section as a chairperson, which reinforces this leadership position as being generically masculine.
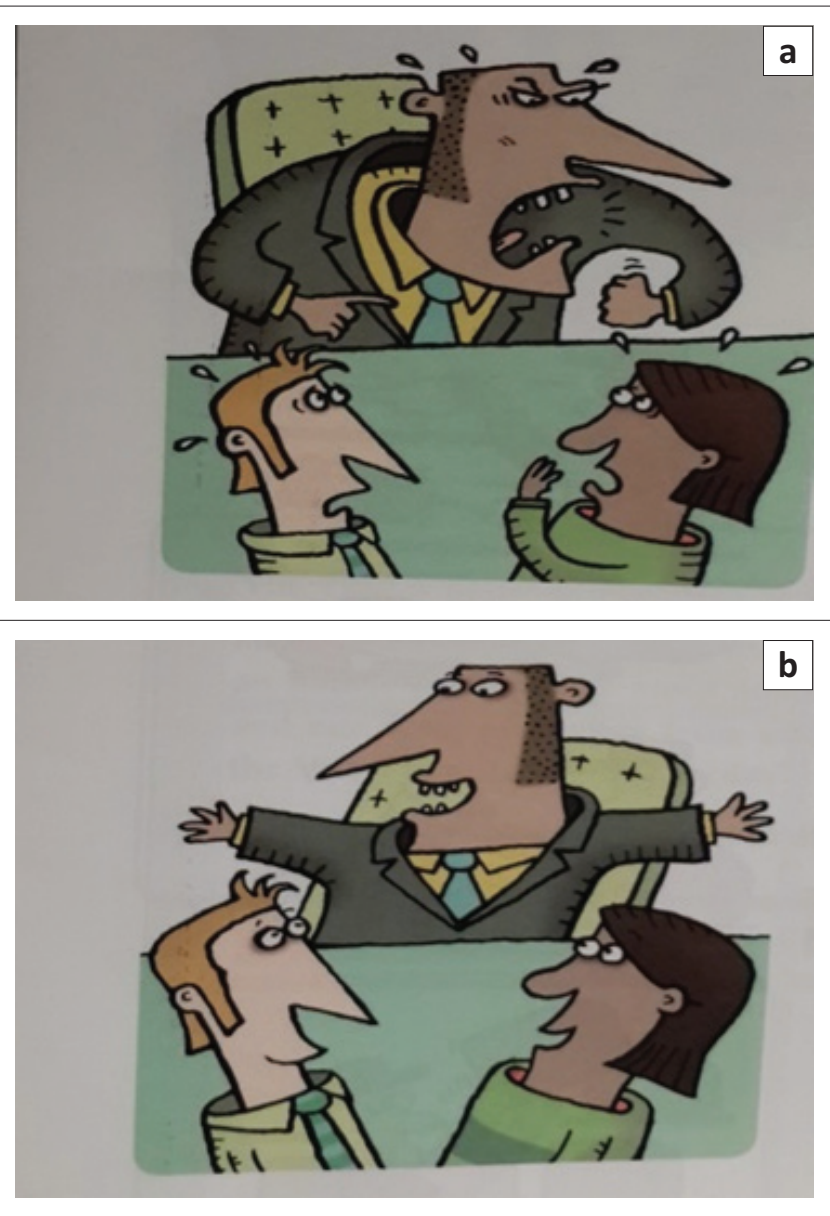

Source: Lesotho 2015, p. 354

FIGURE 1: Depicting management as a male occupation (a) Autocratic manager and (b) Democratic manager.

In the data below, we see how a high-level communication role is assigned a masculine status.

The spokesman announced that we must ensure everyone who uses the roads pays money towards the Road Accident Fund by buying fuel. (South Africa, p. 259)

The generic masculine pronoun is used. The authors once again could have been gender neutral by using 'spokesperson' as opposed to 'spokesman'. The text therefore creates the impression that the spokesperson is male.

\section{Discussion}

The linguistic choices made across the four textbooks of the four different countries create and reflect the unequal power relations between the two genders. 'Firstness' refers to positioning of the male noun or pronoun ahead of the female noun or pronoun in sentences and conversation (Sugino 1998). Male firstness occurred frequently in the four textbooks. The female pronoun was consistently relegated to second-place after the male pronoun, making masculine first in importance and female second.

What also emerged from the data is that the lower frequency of positioning the female noun or pronoun ahead of the male noun or pronoun in sentences and conversation was evident 
particularly across the Lesotho, South African and Swaziland textbooks. There was no mention of the female noun or pronoun ahead of the male noun in sentences and conversations in the Zimbabwean textbooks. This omission is reflective of the prevailing gender insensitive ethos in Zimbabwe. As such, one can therefore expect textbook writers not to digress from 'official' value positions (Carter 2013:6).

The overall trend across the textbooks from all four countries reflects frequent depiction of masculine linguistic choices before feminine linguistic choices. This marks a distinct instance of how the hidden curriculum in learning materials might foster polarised gender identities and promote gender inequality.

These findings suggest what has been described as discoursal marginalisation of discourse partners, especially females which indicates male dominance and an engendering of female stereotypes as trivial or unimportant (Davis 1995; Hartman \& Judd 1978; Pillay \& Maistry 2013; Porreca 1984). Such automatic ordering reinforces the second-place status of women which reflects women as unimportant and minor (Festante 2013). The traditional order of mention, which is often found in texts, reflects a traditional perception of male supremacy: '... let us keep a natural order and set the man before the women' (Eckert \& McConnell-Ginet 2003:34; Hartman \& Judd 1978).

In the texts, males also initiate more dialogue than females a phenomenon that might be relatively easy to rectify if this aspect was in the consciousness of the writer. To cite two example - in the Lesotho textbook (p. 13) and the South African textbook (p. 16), men spoke more and longer than women in mixed-gender conversations. The case studies also foregrounded more masculine narratives of success in the business sector as compared to those of women.

Gender-free language might contribute to acceptance of each human being without dominance of one group (Baghdadi 2012), because language determines the socio-cultural generalisations of a society and forms a part of society's collective consciousness. Pitting the above findings against the literature reviewed, revealed that the depiction of firstness of masculine pronoun analysed, was not unique or different from other parts of the world.

Because selection of subject matter for inclusion in textbooks is a highly political exercise, it is knowledge on the powerful group that dominates in the textbooks, while the less powerful group is included only in passing (Apple 1991). This explains why women, as a less powerful group, are marginalised and subordinated to second-place status across the four textbooks.

Also evident across the four textbooks are the generic terms 'he' and '-man'. Feminist linguistic scholars view this as an indirect way of excluding females (Lee \& Collins 2010) as was evident across the four textbooks under analysis. This perspective is seen as contributing to the creation of gender roles that separate females and males, and restrict them occupationally. The association of the term '-man' seems to suggest that 'this is the natural order of things' (Fowler 1991:15). The use of gender-unfair language, especially of the masculine generic, restricts the visibility of women, and the cognitive (un)availability of female exemplars presents a barren context from which both female and female learners might benefit.

The content of the text depends on the authors, and the way they see and treat gender (Baghdadi 2012). When designing a textbook, authors attempt to present the most common and prevailing conceptions of gender in society. The gender-biased use of language across the four textbooks suggests that textbook authors lack high-level gender awareness and that their focus on disciplinary content takes precedence over potentially prejudicial content. This notion is supported by the findings of Sugino (1998), Skliar (2009), and Pillay and Maistry (2013). The gender bias of the generic pronoun 'he' and '-man' used in the four textbooks has the potential to reinforce the stereotypical assumption that the world of business is an exclusively masculine space, depriving the potential reader of a richer, inclusive discourse. As Lee and Collins (2010:12) rightfully argue, the failure to provide equitable learning through sexist language is 'potentially more dangerous', because it renders women invisible by evoking mental images of males 'as the prototype even for the sex-neutral concept'. Thus, the four textbooks tend to be discriminatory by nature, as they largely represent knowledge from the dominant groups (Aronowitz \& Giroux 1991). It therefore becomes apparent that knowledge from the powerful is what dominates the textbooks, while perspectives of the less powerful are incorporated under the umbrella of the discourse of dominant groups (Apple \& Christian-Smith 1991).

\section{Conclusion}

We have shown in this article that women in the written and visual text of the textbooks studied are marginalised, subordinated, stereotyped and given second-place status to that of males (Hartman \& Judd 1978; Lee \& Collins 2010). The most common form of marginalisation was underrepresentation, while stereotyping largely happened through discourse marginalisation. As textbooks are foregrounded as the official and authorised texts by the state, they are considered authoritative and accurate by teachers and learners who are willing users thereof. The subliminal message projected through discourse marginalisation in the selected textbooks is that women are only deserving of second-place status.

However, although the textbooks have these biased representations, teachers and learners need not remain trapped in them; they can use them as a tool to generate alternate thinking. Merely changing the representation of male to female is not going to solve the problem of gender bias in society; it might require discursive practices well beyond technical cleansing. The intention of the textbook writers may not be malicious nor to deliberately subjugate 
women yet, it happens in a way that is implicit. Critical teacher education is needed to rupture these hidden biases. There might also be a need for textbook writers to deconstruct their own ideological assumptions of gender.

\section{Acknowledgements Competing interests}

The authors declare that they have no financial or personal relationships which may have inappropriately influenced them in writing this article.

\section{Authors' contributions}

P.P. and S.M. conceptualised the study. P.P. wrote the first draft and conducted the literature review. S.M. edited the article. All authors read and approved the final version of the manuscript.

\section{References}

Aikman, S. \& Unterhalter, E., 2005, Beyond access: Transforming policy and practice for gender equality in education, Oxfam, Oxford.

Amini, M. \& Birjandi, P., 2012, 'Gender bias in the Iranian high school EFL textbooks, English', Language Teaching 5(2), 134-147. https://doi.org/10.5539/elt.v5n2p134

Apple, M.W., 2001, 'Educational and curricular restructuring and the neo-liberal and neo-conservative agendas: Interview with Michael Apple', Curriculo sem Fronteiras 1(1), i-xxvi.

Apple, M. \& Christian-Smith, L., 1991, The politics of the textbook, Routledge, New York. Aronowitz, S. \& Giroux, H., 1991, Postmodern education, University of Minnesota Press, Minneapolis, MN.

Baghdadi, M., 2012, 'A comparison of gender representation in English (EFL) and Arabic (AFL) textbooks in Iran: A critical discourse analysis', Unpublished MA dissertation, California State University, Long Beach.

Bahman, M. \& Rahimi, A., 2010, 'Gender representation in EFL materials: An analysis of English textbooks of Iranian high schools', Procedia - Social and Behavioural Sciences 9, 273-277. https://doi.org/10.1016/j.sbspro.2010.12.149

Baxter, J., 2002, 'Competing discourses in the classroom: A post-structuralist discourse analysis of girls' and boys' speech in public contexts', Discourse \& Society 13(6) 827-842. https://doi.org/10.1177/0957926502013006760

Bhana, D., 2009, "'Boys will be boys." What do early childhood teachers have to do with it?', Educational Review 61, 327-339. https://doi.org/10.1080/0013 1910903045963

Butler, J., 1990, Gender trouble: Feminism and the subversion of identity, Routledge, New York.

Cameron, K.S., Ireland, R.D., Lussier, R.N., New, J.R. \& Robbins, S.P., 2003, 'Management textbooks as propaganda', Journal of Management Education 27(6), 711. https:// doi.org/10.1177/1052562903257942

Carter, D., 2013, 'President Mugabe uses inauguration speech to say: "Homosexuality a filthy, filthy disease"', Pink News Africa, viewed 23 August 2013, from http:// www.pinknews.co.uk/2013/08/23/president-mugabe-uses-inauguration-speechto-say-homosexuality-a-filthy-filthy-disease/

Collison, D.J., 2003, 'Corporate propaganda: Its implications for accounting and accountability', Accounting, Auditing and Accountability Journal 16, 853-886. https://doi.org/10.1108/09513570310505989

Crawford, K., 2003, 'The role and purpose of textbooks', International Journal of Historical Learning, Teaching and Research 3(2), 5-11.

Davids, R., 2013, 'An exploration of the ideology in economic and management sciences textbooks: A critical discourse analysis', Unpublished MA dissertation, sciences textbooks: A critical discourse analysis',
University of KwaZulu-Natal, Durban, South Africa.

Davis, L.J., 1995, Enforcing normalcy: Disability, deafness, and the body, Verso, New York. Deleuze, G., 1988, Foucault, University of Minnesota Press, Minneapolis, MN.

Eckert, P. \& McConnell-Ginet, S., 2003, Language and gender, Cambridge University Press, New York.

Engelbrecht, A., 2007, 'The impact of role reversal in representational practices in history textbooks after Apartheid', South African Journal of Education 28, 19-541.

Eric, R., 2011, 'Politics of textbook adoption', Phi Delta Kappan 62(4), 275-278.

Fairclough, N., 2001, Language and power, Pearson Education Limited, Harlow.

Fan, J. \& Zhu, P., 2007, 'Charles Morris's semiotic model and analytical studies of visual and verbal representations in technical communication', Journal of Technical Writing and Communication 36(2), 121-139. https://doi.org/10.2190/B8XBVY4R-R792-DQJG
Festante, R., 2013, An introduction to the theory of gender-neutral language, GRIN Verlag, Norderstedt.

Foroutan, Y., 2012, 'Gender representation in school textbooks in Iran: The place of languages', Current Sociology 60(6), 771-787. https://doi.org/10.1177/001139 2112459744

Foster, S., 2011, 'Dominant traditions in international textbook research and revision', Education Inquiry 2(1), 520. https://doi.org/10.3402/edui.v2i1.21959

Foster, S. \& Crawford, K., 2006, 'The critical importance of history textbook research', in S. Foster \& K. Crawford (eds.), What shall we tell the children? International perspectives on school history textbooks, pp. 1-23, Information Age Publishing Inc., Charlotte, NC.

Foucault, M., 1991, Discipline and punish: The birth of a prison, Penguin, London.

Fowler, R., 1991, Language in the news. Discourse and ideology in the press, Routledge, London.

Hartman, P.L. \& Judd, E.L., 1978, 'Sexism and TESOL materials', TESOL Quarterly 12, 383-393. https://doi.org/10.2307/3586137

Healy, D., 2010, 'The representation of women and men in a modern EFL textbook: Are popular textbooks gender biased?', Memoirs Osaka Journal of Technology 54(2), 91-100.

Huckin, T., 1997, 'Critical discourse analysis', Journal of TESOL 7, 560-572.

Lee, J.F.K. \& Collins, P., 2010, 'Australian English-language textbooks: The gender issues', Gender and Education 21(4), 353-370. https://doi.org/10.1080/09540250802392257

Machin, D. \& Mayr, A., 2012, How to do critical discourse analysis, Sage, London.

Mahlomaholo, M.G., 2010, 'Towards sustainable empowering learning environments: Unmasking apartheid legacies through scholarship of engagement', South African Journal of Higher Education 24, 287-301.

McPhail, K., 1996, 'Accounting education and the ethical construction of students: A Foucaldian perspective', Critical Perspective on Accounting 10(5), 833-866.

Morojele, P., 2010, 'Feminism matters in the primary school: A case from Lesotho', Agenda 24, 82-87.

Morojele, P., 2012, 'What does it mean to be a girl? Implications of girls' and boys' experience of gender roles in rural Lesotho primary schools', Education as Change 5(1), 133-147.

Mukundan, J. \& Nimehchisalem, V., 2008, 'Gender representation in Malaysian secondary school English language textbooks', Indonesian Journal of English Language Teaching 25, 115-136.

Mustedanagic, A., 2010, Gender in English language and EFL textbooks, Term paper, Halmstad University, Högskola.

Naidoo, L.J., 2014, 'Economic representations of HIV/AIDS in contemporary grade 11 business studies textbooks: A critical discourse analysis', Unpublished master's dissertation, University of KwaZulu-Natal, Durban, South Africa.

Nene, N.P., 2014, 'An analysis of the visual images of women in Grade 12 South African history textbooks', Unpublished MEd dissertation, University of KwaZulu-Natal, Durban, South Africa.

Osborne, K., 2004, 'Canadian history in schools', Historica 43(2), 129-139.

Pillay, P., 2013, 'Gender representation in contemporary Grade 10 Business Studies textbooks', Unpublished MA dissertation, University of KwaZulu-Natal, Durban, South Africa.

Pingle, F., 2010, The deconstruction of human identity in concentration camps: The contribution of social sciences to an analysis of behaviour under extreme conditions, Unipress, Tampa, FL.

Porreca, K.L., 1984, 'Sexism in current ESL textbooks', TESOL Quarterly 18, 704-707. https://doi.org/10.2307/3586584

Rosenberg, R., 2001, Women's studies: An interdisciplinary anthology, Peter Lang, New York.

Scott, J.W., 1988, 'Deconstructing equality-versus-difference: Or, the uses of poststructuralist theory for feminism', Feminist Studies 14(1), 33-50. https://doi. org/10.2307/3177997

Skliar, O.S., 2009, 'Gender representations and gender bias in ELT textbooks published in the Middle East: A case study of ELT textbooks published in Turkey and Iran', Unpublished MA dissertation, Middle East Technical University, Turkey.

Sleeter, C.E. \& Grant, C.A., 1991, 'Race, class, gender, and disability bias in current textbooks', in M.W. Apple \& L.K. Christian-Smith (eds.), The politics of the textbook, pp. 78-110, Routledge, New York.

Sugino, T., 1998, 'Gender stereotypes and children's literature', The Language Teacher 22(6), 112-120.

Swainson, N., 2016, Redressing gender inequalities in education: A review of constraints and priorities in Malawi, Zambia and Zimbabwe, Report commissioned by BDDCA, DFID Education Study, Harare.

United Nations Summit, 2010, Overcoming inequality: Why governance matters, EFA Global Monitoring Report, Oxford University Press, Oxford.

Weedon, C., 1987, Feminist practice and poststructuralist theory, Africanwell, Cambridge, MA.

Weedon, C., 1997, Feminist practice and poststructuralist theory, 2nd edn. Africanwell, Oxford.

Wetherell, M., 1999, 'Discourse analysis', in C. Davidson \& M. Tolich (eds.), Social science research in New Zealand: Many paths to understanding, pp. 265-276, Longman, Auckland.

Zhang, W., 2012, 'Fair value accounting as an instrument of neoliberalism in China', Unpublished PhD thesis, University of Wollongong, Northfields Ave, Australia. 